\title{
IMPACT OF PARTICLE SIZE OF KWATHYADRAVYA (DECOCTION POWDER) IN THE PREPARATION OF PHALTRIKADI KWATH
}

\section{DILEEP SINGH BAGHEL ${ }^{1 *}$, ANAND KUMAR CHAUDHARY ${ }^{2}$}

${ }^{1}$ Department of Ayurvedic Pharmacy, School of Pharmaceutical Sciences, Lovely Professional University, Phagwara, Punjab, India. ${ }^{2}$ Department of Rasa Shastra and Bhaishjya Kalpana, (Ayurvedic Pharmaceutics), Faculty of Ayurveda, Institute of Medical Sciences, Banaras Hindu University, Varanasi, Uttar Pradesh, India. Email: baghel_12@rediffmail.com

Received: 27 November 2017, Revised and Accepted: 08 January 2018

ABSTRACT

Objectives: The study was aimed to investigate the effects of particle size, vessel used, and extraction time in the preparation of Phaltrikadi kwath.

Methods: The particle size of Kwath dravya (solute) was cut into the size of $0.5 \mathrm{~cm}, 1 \mathrm{~cm}, 1.5 \mathrm{~cm}, 2 \mathrm{~cm}$, and coarse powder (pass $60^{\#)}$. The ratios of solvent (water) were 16 times of solute and boiling was done till $1 / 4^{\text {th }}$ part of the solvent was remain. The provided extraction time was also varied 5.5 to $6 \mathrm{~h}$ at temperature range $23^{\circ} \mathrm{C}-90^{\circ} \mathrm{C}$. Phaltrikadi kwath was prepared as per formula mentioned in "Sharngadhar samhita" Madhyam khand $2 / 77$.

Results: Total 15 samples of Phaltrikadi kwath were prepared and analyzed for physicochemical and phytochemical parameters, from obtained value, it was confirmed that extraction procedure with varied particle size significantly affected the yield of active pharmaceutical ingredients in prepared Phaltrikadi kwath. Coarse particle sizes can produce a higher yield. Moreover, a longer extraction time produces a higher yield.

Conclusion: Kwath (decoction) prepared by particle size $1.5 \mathrm{~cm}$ and $2.0 \mathrm{~cm}$ may be more therapeutically effective, as it has total solid content more than 6\%, it proves that "Yavakuta" phenomena of Ayurvedic classics.

Keywords: Kwath, Decoction, Particle size, Kwathyadravya, Phaltrikadi kwath.

(C) 2018 The Authors. Published by Innovare Academic Sciences Pvt Ltd. This is an open access article under the CC BY license (http://creativecommons. org/licenses/by/4. 0/) DOI: http://dx.doi.org/10.22159/ajpcr.2018.v11i4.23977

\section{INTRODUCTION}

Kwath (decoction) is the process in which the water-soluble and heat stable constituent of hard and woody crude drugs are extracted out. Kwath (aqueous liquid dosage form) has considered among five fundamental dosage forms of Ayurvedic formulation (Table 1). Kwath (decoction) is used alone or in preparation of several derivative Kalpana of Ayurvedic therapeutic. Kwath churna (decoction powder) is the compounded coarse powder which intended for use whenever decoction is required [1-15]. Phaltrikadi kwath churna is a polyherbal formulation consists of Emblica officinalis, Terminalia chebula, Terminalia bellerica, Tinospora cordifolia, Azadirachta indica, Adhatoda vasica, Picrorhiza kurroa, and Swertia chirayita in equal quantity [6]. Ayurvedic and modern literature have different opinion among scholar's regarding the size of Kwathyadravya (decoction coarse powder) [1-15], so for solving all these controversies, the present work is hypothesized to prepare Phaltrikadi kwath with the help of Kwath dravya (different size) as per the mentioned method and compare on the basis of physicochemical parameters which help for determining the suitable size of Kwathyadravya in the preparation of Kwath kalpa.

\section{METHODS}

All the authenticated raw herbs (Figs. 1 and 2) used for the preparation of Phaltrikadi kwath were collected from the Ayurvedic Pharmacy, Gujarat Ayurved University, Jamnagar, Gujarat, India (Table 1).

\section{Method of preparation of Phaltrikadi Kwath}

Phaltrikadi kwath was prepared according to the procedure mentioned in the "Sharngadhar samhita" Madhyam khand 2/77 [6]. Total 15 samples of Phalatrikadi kwath were prepared, i.e. 3 samples were coarsely powdered (Fig. 3), 3 were of $0.5 \mathrm{~cm}$ (Fig. 4), 3 were of $1 \mathrm{~cm}$ (Fig. 5), 3 were of $1.5 \mathrm{~cm}$ (Fig. 6), and 3 were of $2 \mathrm{~cm}$ (Fig. 7) in particle size.
Here, in every batch, one sample was prepared using Mritika patra and two were prepared in steel pan (Fig. 8) (Table 2).

\section{Physicochemical investigation}

Different physicochemical investigations of raw materials (Table 1), Kwath churna (Table 3) and prepared Kwath (Table 4) were carried out using standard pharmacopoeial methods including organoleptic parameters, foreign matter, loss on drying, total ash, acid-insoluble ash, extractive values, $\mathrm{pH}$ determination, and total solid content [16-24].

Qualitative tests

The qualitative tests were carried out for the detection of alkaloids, tannins, glycosides, steroids, carbohydrates, and amino acids as per the standard testing protocol mentioned in the reference [19-24].

\section{Quantitative evaluation}

\section{Quantitative estimation of alkaloids}

The samples were estimated quantitatively for total alkaloid content by gravimetric method mentioned as per the standard testing protocol mentioned in the reference [19-25].

\section{Quantitative estimation of tannins}

Tannin estimation was done by volumetric method mentioned as per the standard testing protocol mentioned in the reference [19-23].

\section{DISCUSSION}

The present study was conducted to explore the concept of "Kwath kalpana" from Samhita kala to recent modern era. Here, efforts were made to remove the controversy regarding the particle size of "Kwathya dravya" (solute). Kwath (decoction) is aqueous solutions contains the properties of any substances that have been boiled in it. The purpose 
of Kwath (herbal decoction) is to extract the water-soluble constituent of herbs by boiling. Quantum of heat and duration of heating is prime concern for the preparation of Kwath. This remedy is easy to make, but need careful attention and some more time until one becomes familiar with the process. The yield, the color and the taste can vary from batch to batch, but the general, the final product is in liquid form, which looks somewhat like apple cider or light honey. Soaking of Kwathya dravya (solute) results in the softening of the drug due to diffusion of
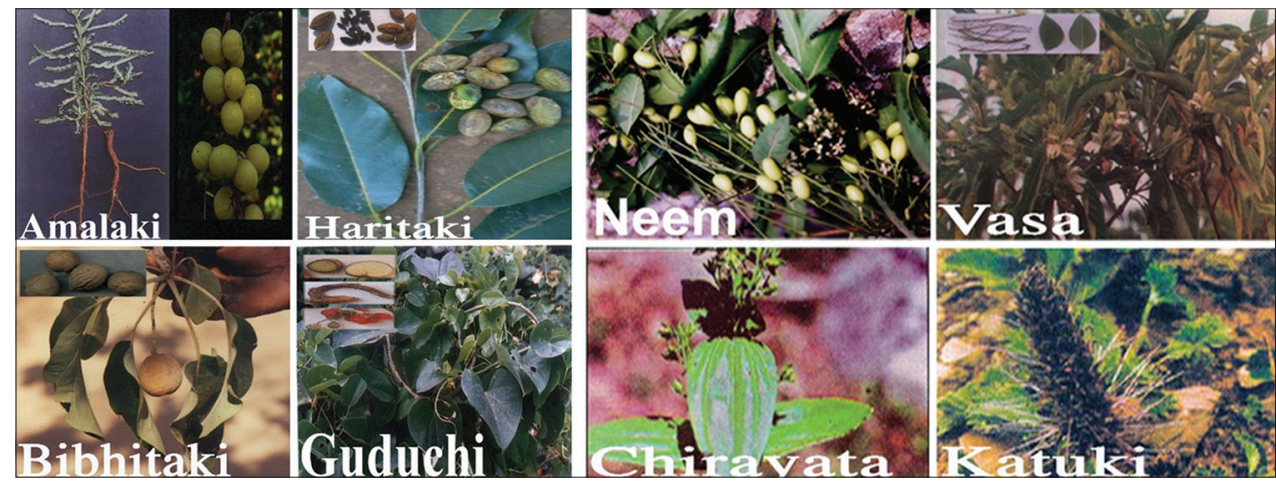

Fig. 1: Raw plant material

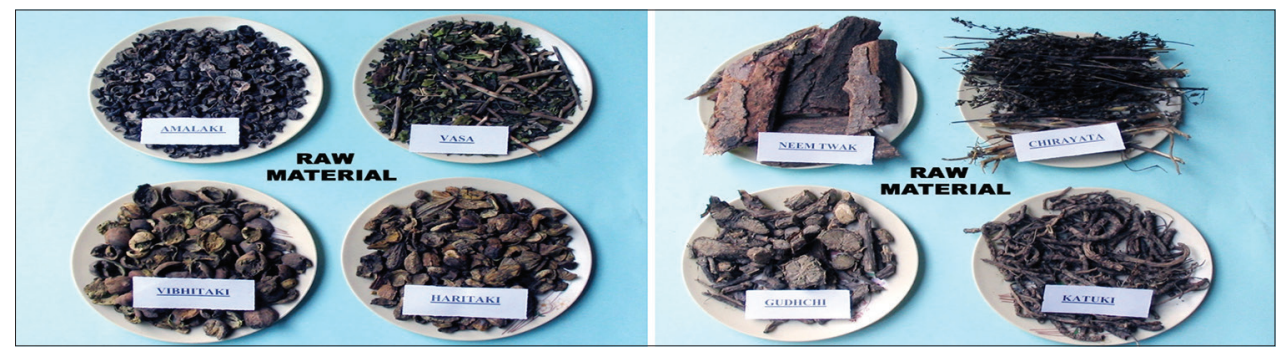

Fig. 2: Raw plant material (Part used)

Table 1: Physicochemical evaluation of raw materials used for Phaltrikadi kwath

\begin{tabular}{|c|c|c|c|c|c|}
\hline \multirow{2}{*}{$\begin{array}{l}\text { Drug } \\
\text { name }\end{array}$} & \multicolumn{5}{|l|}{ Parameter } \\
\hline & $\begin{array}{l}\text { Foreign matter } \\
\% \mathrm{w} / \mathrm{w}\end{array}$ & $\begin{array}{l}\text { Total ash } \\
\% \mathrm{w} / \mathrm{w}\end{array}$ & $\begin{array}{l}\text { Acid-insoluble } \\
\text { Ash } \% \mathrm{w} / \mathrm{w}\end{array}$ & $\begin{array}{l}\text { Alcohol-soluble } \\
\text { extractive } \% \mathrm{w} / \mathrm{w}\end{array}$ & $\begin{array}{l}\text { Water-soluble } \\
\text { extractive } \% \mathrm{w} / \mathrm{w}\end{array}$ \\
\hline Bibhitaki & 5.38 & 5.55 & 0.68 & 40.57 & 60.52 \\
\hline Amalaki & 3.27 & 5.69 & 1.22 & 57.22 & 62.5 \\
\hline Guduchi & 8.99 & 12.82 & 2.87 & 38.77 & 48.32 \\
\hline Katuki & 12.66 & 4.32 & 0.87 & 47.98 & 58.88 \\
\hline Chirayata & 3.23 & 5.47 & 0.92 & 53.48 & 60.90 \\
\hline Vasa & 7.38 & 16.97 & 0.78 & 50.90 & 58.92 \\
\hline Neem chhal & Nil & 4.91 & 1.32 & 54.32 & 61.39 \\
\hline
\end{tabular}

Table 2: Showing the facts during preparation of Phaltrikadi kwath

\begin{tabular}{|c|c|c|c|c|c|c|}
\hline $\begin{array}{l}\text { Sample } \\
\text { number }\end{array}$ & $\begin{array}{l}\text { Kwath dravya particle } \\
\text { size }\end{array}$ & Vessel used & $\begin{array}{l}\text { Temperature } \\
\text { range }\left({ }^{\circ} \mathrm{C}\right)\end{array}$ & $\begin{array}{l}\text { Time taken in } \\
\text { Paka (min) }\end{array}$ & $\begin{array}{l}\text { Initial volume } \\
\text { of water (ml) }\end{array}$ & $\begin{array}{l}\text { Volume of decoction (finished } \\
\text { product) }(\mathrm{ml})\end{array}$ \\
\hline 1 & \multirow[t]{3}{*}{ Coarse powder (pass 60") } & Stainless steel & $23-90$ & 330 & 4100 & 512 \\
\hline 2 & & Stainless steel & $23-90$ & 330 & 4100 & 500 \\
\hline 3 & & Mritika patra & $20-80$ & 330 & 4100 & 515 \\
\hline 4 & \multirow[t]{3}{*}{$0.5 \mathrm{~cm}$} & Stainless steel & $24-85$ & 330 & 4100 & 510 \\
\hline 5 & & Stainless steel & $24-89$ & 330 & 4100 & 505 \\
\hline 6 & & Mritika patra & $19-79$ & 330 & 4100 & 518 \\
\hline 8 & \multirow{2}{*}{$1.0 \mathrm{~cm}$} & Stainless steel & $24-88$ & 360 & 4100 & 520 \\
\hline 9 & & Mritika patra & $22-85$ & 360 & 4100 & 500 \\
\hline 10 & \multirow[t]{3}{*}{$1.5 \mathrm{~cm}$} & Stainless steel & $23-81$ & 330 & 4100 & 520 \\
\hline 11 & & Stainless steel & $23-90$ & 330 & 4100 & 509 \\
\hline 12 & & Mritika patra & $20-81$ & 360 & 4100 & 522 \\
\hline 13 & \multirow[t]{3}{*}{$2.0 \mathrm{~cm}$} & Stainless steel & $22-84$ & 330 & 4100 & 500 \\
\hline 14 & & Stainless steel & $22-86$ & 330 & 4100 & 510 \\
\hline 15 & & Mritika patra & $19-80$ & 330 & 4100 & 520 \\
\hline
\end{tabular}


liquid into the Kwathya dravya (solute) because of the osmosis. Due to the presence of hydroxyl group, the Kwathya dravya (solute) swells which result in the increased diffusion pressure inside the cells, which ultimately leads to the bursting of the cell wall. This process is enhanced by the vigorous boiling and agitation during the Kwath nirmana (preparation of decoction). The water diffuses into the Kwathya dravya (solute), dissolves the water-soluble constituents and discharges it to the liquid media due to collapsement of boundary layer which results in the transfer of water-soluble principles into the solvent (water). The continuous heating and agitation during the Kwath nirmana enhance the extraction process by weakening the bounds, thereby separating the hydrophobic substances from hydrophilic substances.

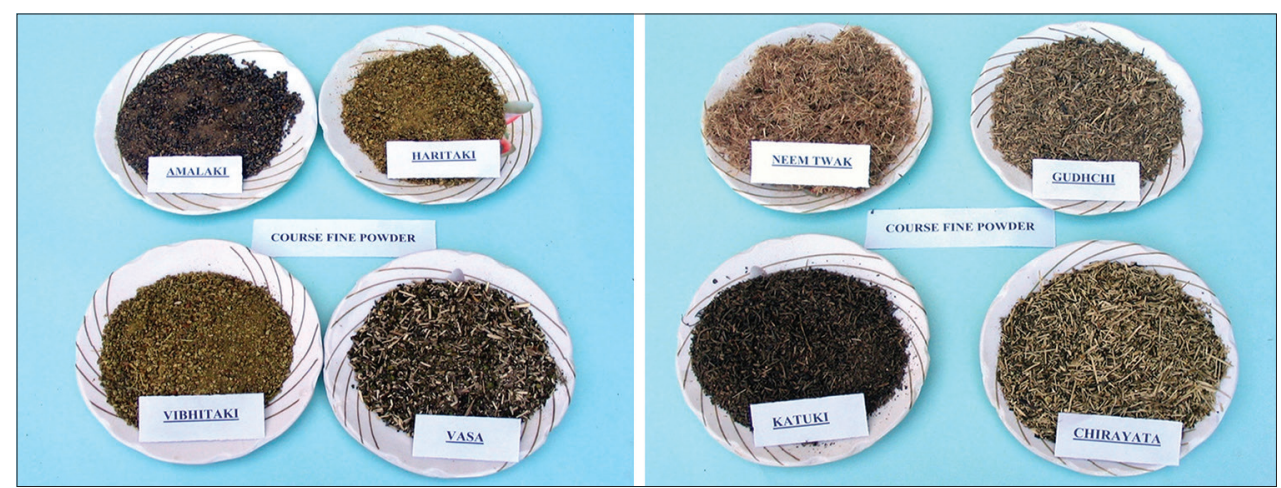

Fig. 3: Raw plant material (Coarsely powdered)

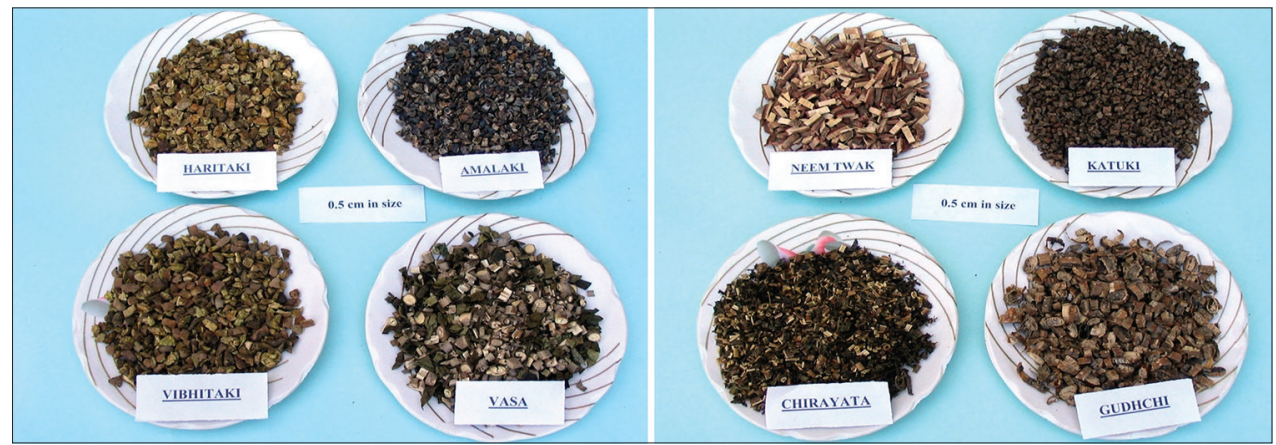

Fig. 4: Raw plant material (Particle size $0.5 \mathrm{~cm}$ )

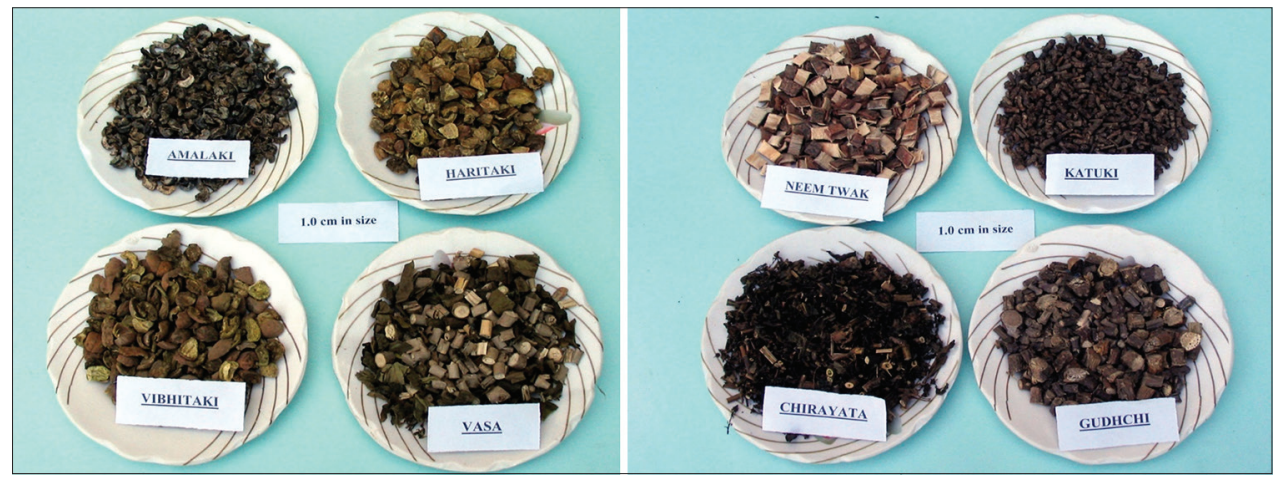

Fig. 5: Raw plant material (Particle size $1 \mathrm{~cm}$ )

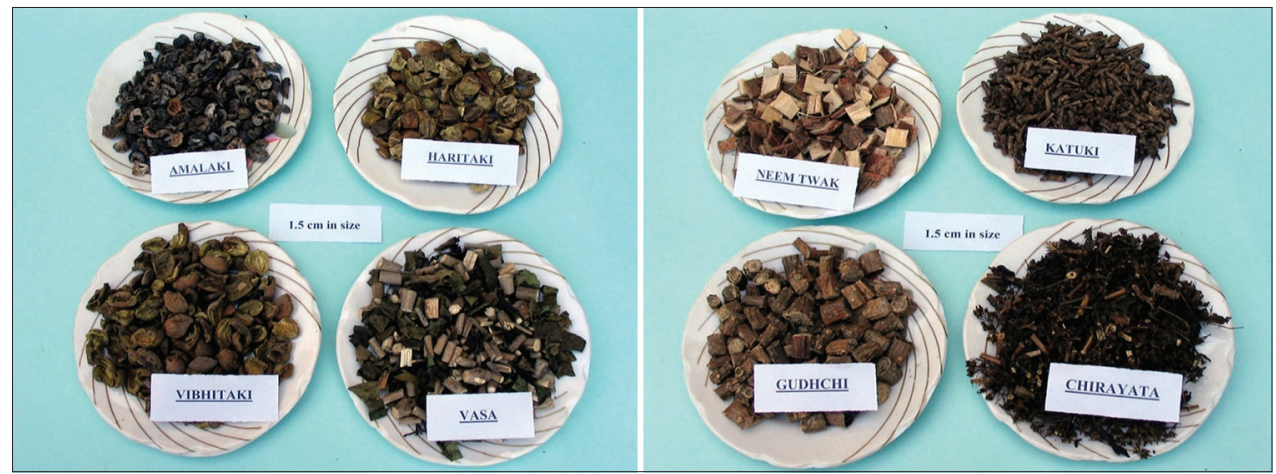

Fig. 6: Raw plant material (Particle size $1.5 \mathrm{~cm}$ ) 


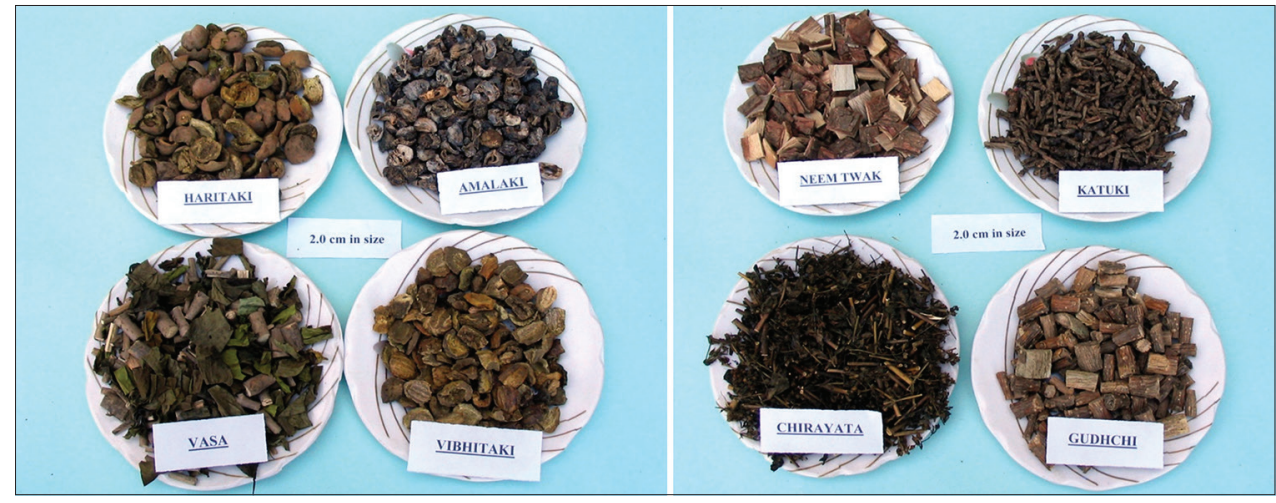

Fig. 7: Raw plant material (Particle size $2 \mathrm{~cm}$ )

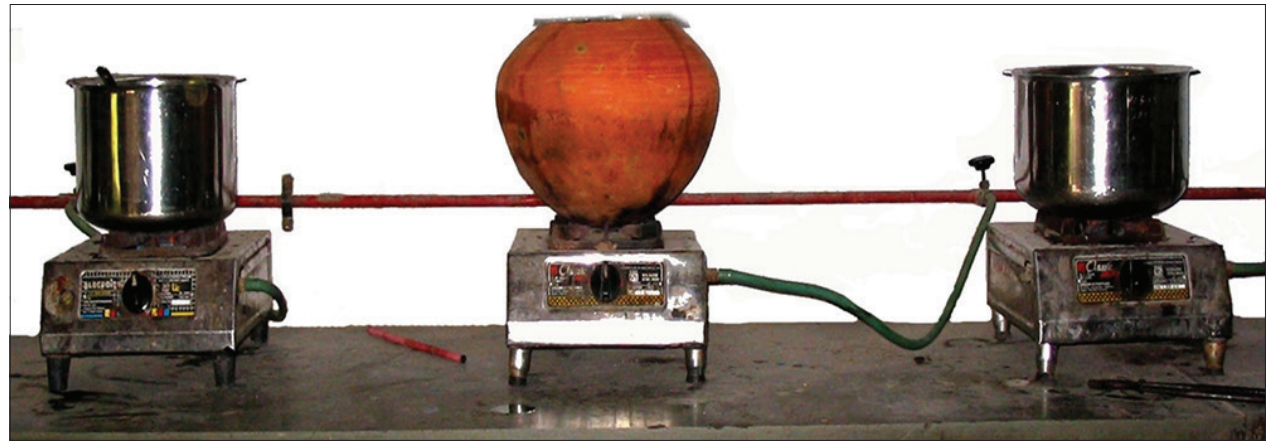

Fig. 8: Vessel used for the preparation of Phaltrikadi kwath

Table 3: Physicochemical evaluation of Phaltrikadi kwath churna

\begin{tabular}{lll}
\hline S. No & Parameter & Observation (\%) \\
\hline 1 & Foreign matter & Nil \\
2 & Loss on drying (at $\left.110^{\circ} \mathrm{C}\right)$ & $11.9 \mathrm{w} / \mathrm{w}$ \\
3 & Total ash $\left(\right.$ at $\left.450^{\circ} \mathrm{C}\right)$ & $5.32 \mathrm{w} / \mathrm{w}$ \\
4 & Acid-insoluble ash & $0.73 \mathrm{w} / \mathrm{w}$ \\
5 & Hexane-soluble extractive value & $1.592 \mathrm{w} / \mathrm{w}$ \\
6 & Benzene soluble extractive value & $3.784 \mathrm{w} / \mathrm{w}$ \\
7 & Chloroform-soluble extractive value & $5.904 \mathrm{w} / \mathrm{w}$ \\
8 & Alcohol-soluble extractive value & $20.46 \mathrm{w} / \mathrm{w}$ \\
9 & Water-soluble extractive value & $26.00 \mathrm{w} / \mathrm{w}$ \\
10 & Qualitative chemical test for alkaloid & Present \\
11 & Qualitative chemical test for tannin & Present \\
12 & Quantitative estimation of alkaloid content & $0.917 \mathrm{w} / \mathrm{w}$ \\
13 & Quantitative estimation of tannin content & $09.90 \mathrm{w} / \mathrm{w}$ \\
\hline
\end{tabular}

Table 4: Physicochemical evaluation of prepared Phaltrikadi kwath

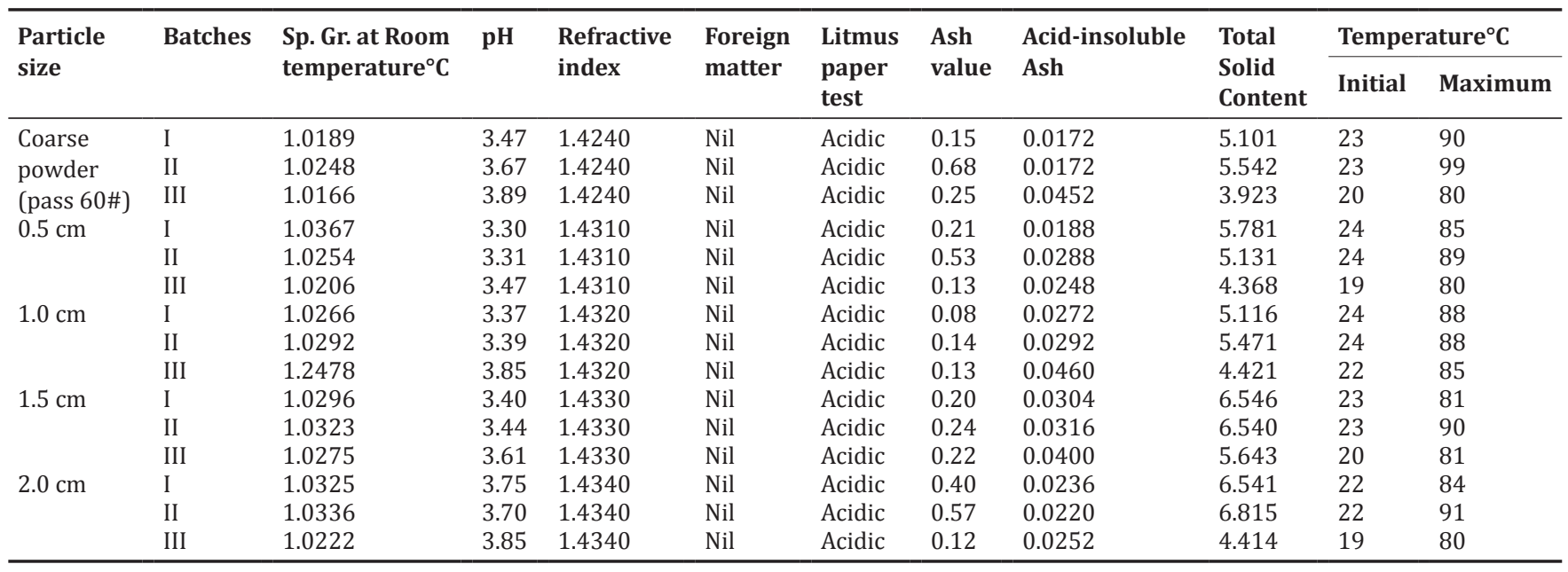


In the present study, as heating device gas stove has been taken. Due to the fast urbanization, it may be quite difficult to use these methods to prepare the drug in a large scale. Nowadays, to cope up with the increasing demands of Ayurvedic preparations it has become quite common to use steam jacketed vessels in place of gas stove. These facilitate to prepare a standard and quality product. Adoption of modern technology in the preparation of Ayurvedic formulation is the need of present era, it permissible and good if we not change the basic principle mentioned in the Ayurvedic classics. Quantum of heat, quantity of water, and duration of heating is a time concern for Kwath nirmana. The purpose is to drive the water-soluble therapeutically active principles from the source drug. During preparation of Kwath, quantum of heat (temperature) was the most important factor for consideration because it may decompose the water-soluble extract which is sensitive toward too much heat, so during the preparation of Kwath mridu agni was maintain throughout the process for each sample, in medium range (not exceed $80^{\circ} \mathrm{C}-90^{\circ} \mathrm{C}$ ) stirring was done in between the Kwath preparation to get the uniform temperature and concentration throughout the solvent and also to protect the burning of drug. Filtration of Kwath was done to remove the exhausted material from Kwath, for this cotton cloth (double folded) is used to separate the exhausted material for obtaining the clear solution of Kwath. Nowadays, due to increasing demand for Ayurvedic products, there is a transfer of traditions to technology. Nowadays, instead of Mritika patra and steel vessel, steam jacketed vessels are used for the manufacturing of Kwath.

There is no much difference of specific gravity of decoction prepared using substance of different particle size was observed it is ranged between 1.0166 and 1.0336. pH of all prepared Kwath samples was in between 3.30 and 3.89 that means all are acidic in nature which was also confirmed by litmus paper test. Total ash of all prepared samples was observed in between $0.08 \%$ and $0.68 \%$. Acid-insoluble ash of sample is also varying from $0.0172 \%$ to $0.046 \%$. Refractive index of all sample varying $1.4240-1.4340$, but there is a remarkable difference in total solid content, it is from $3.923 \%$ to $6.815 \%$.

\section{CONCLUSION}

After reviewing all analytical data, it can be concluded that decoction prepared in Mritika patra had shown higher total ash, acid-insoluble ash, and lesser total solid content in comparison to those samples which were prepared in steel pan. Decoction prepared by particle size $1.5 \mathrm{~cm}$ and $2.0 \mathrm{~cm}$ may be more therapeutically effective, as it has total solid content more than $6 \%$, it proves that "Yavakuta" phenomena of Ayurvedic classics

\section{ACKNOWLEDGMENT}

The authors are thankful to the Institute of Ayurvedic Pharmaceutical Sciences, Gujarat Ayurveda University, Jamnagar, Gujarat, for providing necessary arrangement with infrastructure to complete the research work.

\section{AUTHORS CONTRIBUTIONS}

Dileep Singh Baghel : Principal investigator, performed preparation and analysis on all samples, interpreted data, write manuscript and acted as corresponding author. Dr. Anand Kumar Chaudhary : Guide, supervised development of work, helped in data interpretation, manuscript evaluation and editing.

\section{CONFLICTS OF INTERESTS}

None Declared.

\section{REFERENCES}

1. Tritha SS. In: Uniyal RC, editors. Ayurvedic Encyclopedia. $1^{\text {st }}$ ed. New Delhi, India: Sai Satguru Publications; 1998.

2. Thakkur CG. Introduction to Ayurveda: Basic Indian Medicine. $2^{\text {nd }}$ ed. Printed by J.S. Khamesra for G. Claridge \& Co. Ltd. Jamnagar: Bombay and Published by Shri K.P. Shah. Hon. Secretory. Gulabkunverba Ayurvedic Society; 1976.

3. Ramchandra RK. Bhaishajya Kalpana Vijnanam. $1^{\text {st }}$ ed. Varanasi: Chaukhambha Sanskrit Bhavan; 1998.

4. Shobha GH. A Text Book of Bhaishajya Kalpana. $1^{\text {st }}$ ed. Bangalore: IBH Prakashan; 2000.

5. Das SG. Bhaishajya Ratnaval. $14^{\text {th }}$ ed. Varanasi: Chaukhamba Sanskrit Samsthan; 2001.

6. Pandit SP. Sharandhar Samhita. Commentary of Adhmal's Dipika and Kashiram's Gudharthdipika. $5^{\text {th }}$ ed. Varansi: Madhyam Khanda, Chakhumba Orientalia; 2002.

7. Karan SR, Vaidya BD. Agnivesa's Caraka Samhita. $3^{\text {rd }}$ ed. Varanasi: Chowkhamba Sanskrit Series Office; 1992.

8. Samhita S. Commentary by Dr. Bhaskar Govind Ghanekar. New Delhi: Meherchand Lachamandas Publications; 2002.

9. Hridaya A. Commentaries "Sarwanga Sundara" of Arunadutta and "Ayurveda Rasayana" of Hemadri. Varanasi: Chaukhambha Orientalia; 2002.

10. Vagbhata M. Ashtanga Samgraha. Edited with 'Saroj' Hindi commentary by Dr. Ravi Dutt Tripathi. Delhi: Chaukhambha Sanskrit Pratishthan; 1996.

11. Sangraha AS. $29^{\text {th }}$ ed. Nagpur: Published by Shri Baidhyanath Ayurved Bhawan Pvt., Ltd.; 2004.

12. Carter SJ. Cooper and Gunn; s. Dispensing for Pharmaceutical Students. $12^{\text {th }}$ ed. Delhi: CBS Publishers and Distributors; 1987.

13. Liebermon HA, Kaning JL. Lachmon Lean. The Theory and Practice of Industrial Pharmacy. $3^{\text {rd }}$ ed. Bombay: Varghese Publishing House; 1987.

14. Mittal BM. A Text Book of Pharmaceutical Formulation. $6^{\text {th }}$ ed. Delhi: Vallabha Prakashan; 1994

15. Gennaro AE. Remington's. The Science and Practice of Pharmacy. $20^{\text {th }}$ ed. Vol. I and II. Easton PA: Mack Publishing Company; 2000.

16. Bhanu PS, Zafar R, Panwar R. Herbal drug standardization. Indian Pharm 2005; 4:19-22.

17. Patel PM, Patel NM, Goyal RK. Quality control of herbal products. Indian Pharm 2006;5:26-30.

18. Anonymous. Regional Research Laboratory. Vol. II. Jammu Tawi: Regional Research Laboratory Council of Scientific and Industrial Research; 1999.

19. Gupta AK. Quality Standards of Indian Medicinal Plants. Vol. I. India: Indian Council of Medical Research; 2003.

20. Ahmad RV, Sharma RK Evaluation of Drug for Standardization. Proceedings of WHO Training cum- Workshop. Pharmaceutical Lab for Indian Medicine. Ghaziabad: Ministry of Health and Family Welfare. Government of India; 2001.

21. Harbone JB. Phytochemical Methods: A Guide to Modern Techniques of Plant Analysis. London: Chapman and Hall Ltd.; 1984.

22. Anonymous. The Ayurvedic Formulary of India (AFI). Part I. $2^{\text {nd }}$ Revised Englished. New Delhi: Government of India. Ministry of Health and Family Welfare. Department of Indian System of Medicine and Homeopathy; 2003.

23. Baxi AJ, Shukla VJ. Bhatt UB. Methods of Qualitative Testing of some Ayurvedic Formulations. Jamnagar: Gujarat Ayurved University; 2001 .

24. Keerthiga M, Anand SP. Physicochemical, preliminary phytochemical analysis and antibacterial activity against clinical pathogens of medicinally important orchid Geodorum densiflorum (Lam) Schltr. Int J Pharm Pharm Sci 2014;6:558-61.

25. Prakasia PP, Nair AS. Evaluation of in vitro antioxidant potential of the total crude alkaloid extract of Glycosmis pentaphylla (Retz.) Correa leaves. Int J Pharm Pharm Sci 2016;8:3. 